\title{
Immunohistochemical identification of Vibrio salmonicida in stored tissues of Atlantic salmon Salmo salar from the first known outbreak of cold- water vibriosis ('Hitra disease')
}

\author{
Øystein Evensen ${ }^{1}$, Sigrun Espelid ${ }^{2}$, Tore Håstein ${ }^{1}$ \\ ${ }^{1}$ National Veterinary Institute, PO Box 8156 Dep., N-0033 Oslo 1, Norway \\ ${ }^{2}$ Foundation of Applied Research, University of Tromsø (FORUT), PO Box 2806, Elverhøy, N-9001 Tromsø, Norway
}

\begin{abstract}
Immunohistochemistry based on the avidin-biotin complex method was employed to identify Vibrio salmonicida or its products, in formalin-fixed, paraffin-embedded tissue specimens from Atlantic salmon Salmo salar L. suffering from experimentally induced cold-water vibriosis. The technique was also used to establish the presence of the bacterium in stored tissue specimens collected in 1977 during the first known outbreak of the disease in Norway. Antigens of $V$. salmonicida were specifically identified in tissue specimens from heart, liver, spleen, kidney, and gut by incubation with monoclonal antibodies specific for the bacterium. These findings offer strong evidence for $V$. salmonicida as the causative agent in the first outbreak of the disease, and are consistent with other reports identifying it as the aetiologic agent of cold-water vibriosis.
\end{abstract}

\section{INTRODUCTION}

'Hitra disease', or cold-water vibriosis (CV) was first reported in 1977 from the northern part of Norway (Poppe et al. 1985). No causative agent was identified at that time, and a multifactorial aetiology was suggested, the disease being referred to as a 'haemorrhagic syndrome', and later as 'Hitra disease' (Poppe et al. 1985). In subsequent discussions on the aetiology of the disease, a nutritional deficiency was suggested, especially a lack of dietary vitamin $\mathrm{E}$ and selenium (Fjølstad \& Heyeraas 1985, Poppe et al. 1985, 1986). Other workers have postulated that the condition is infectious, basing their views on the isolation of Vibrio salmonicida from diseased fish (Egidius et al. 1981, Egidius et al. 1984, Holm et al. 1985), and on infection studies in which the disease has been successfully reproduced using the bacterium (Bruno et al. 1985, Holm 1985). Recently, it has been demonstrated that vaccination against $V$. salmonicida gives very good protection against the disease (Holm \& Jørgensen 1987 , Lillehaug 1990). At present the term cold-water vibriosis is generally accepted as the name for the condition.

(c) Inter-Research/Printed in Germany
Vibrio salmonicida exhibits a species-specific antigen called VS-P1, and 2 monoclonal antibodies (MAbs) raised against the bacterium (derived from clones 2B5 and 7F3) have been reported to identify an epitope on VS-P1 unique for $V$. salmonicida (Espelid et al. 1988 , Bøgwald et al. 1990).

The objectives of the present study were (1) to develop an immunohistochemical technique to identify Vibrio salmonicida or its products in formalin-fixed and paraffin-embedded tissue by the application of monoclonal antibodies raised against the VS-P1 antigen, and (2) to establish the presence of the same bacterium in stored tissue specimens collected during the first known outbreak of the disease.

\section{MATERIALS AND METHODS}

Controls. Organ samples from positive control fish, Atlantic salmon Salmo salar, were collected during an infection experiment with Vibrio salmonicida carried out in 1989. Atlantic salmon with an average weight of 55 to $60 \mathrm{~g}$ were used in the experiment. The fish were held in $1 \mathrm{~m}^{3}$ tanks with a water temperature of 7 to 

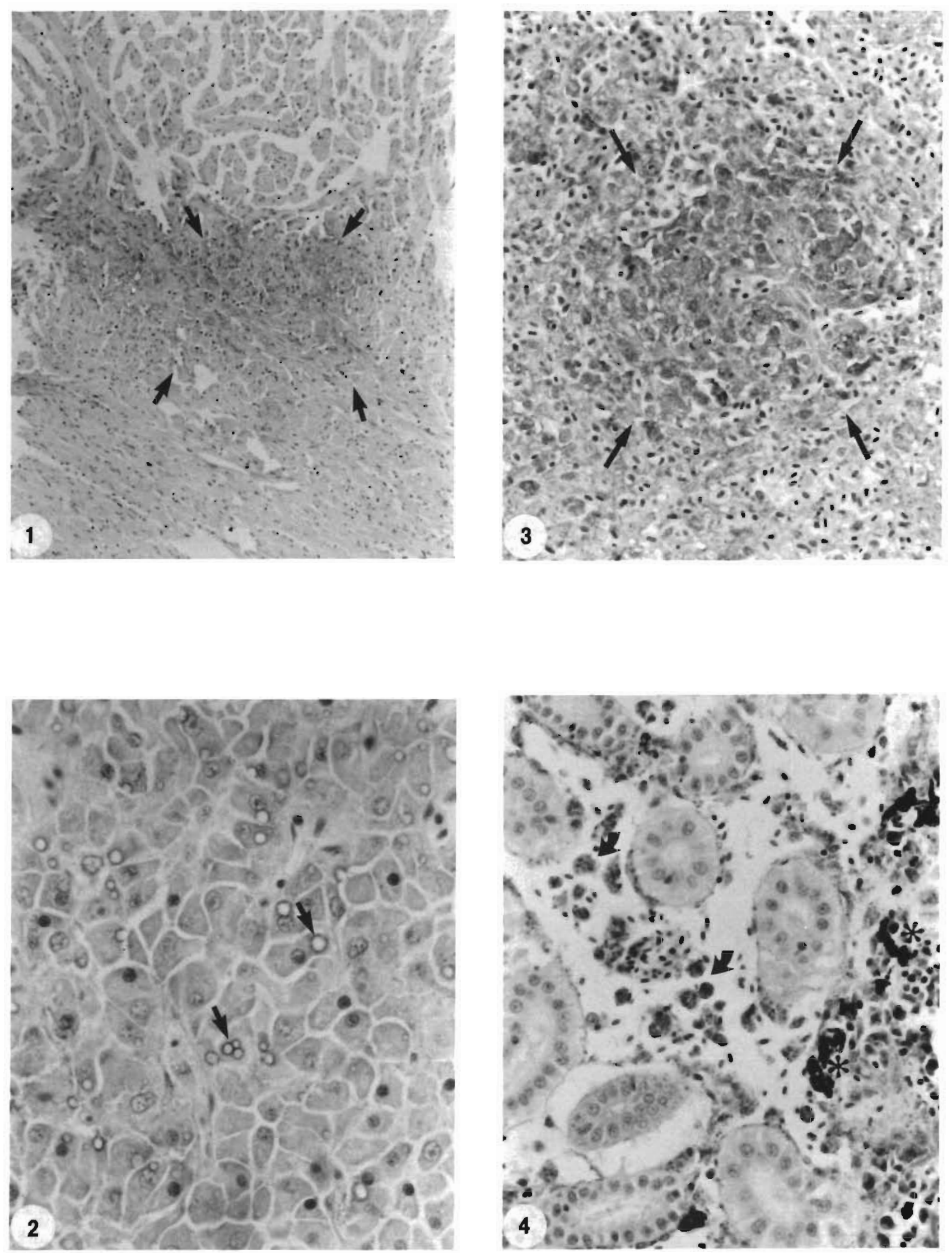


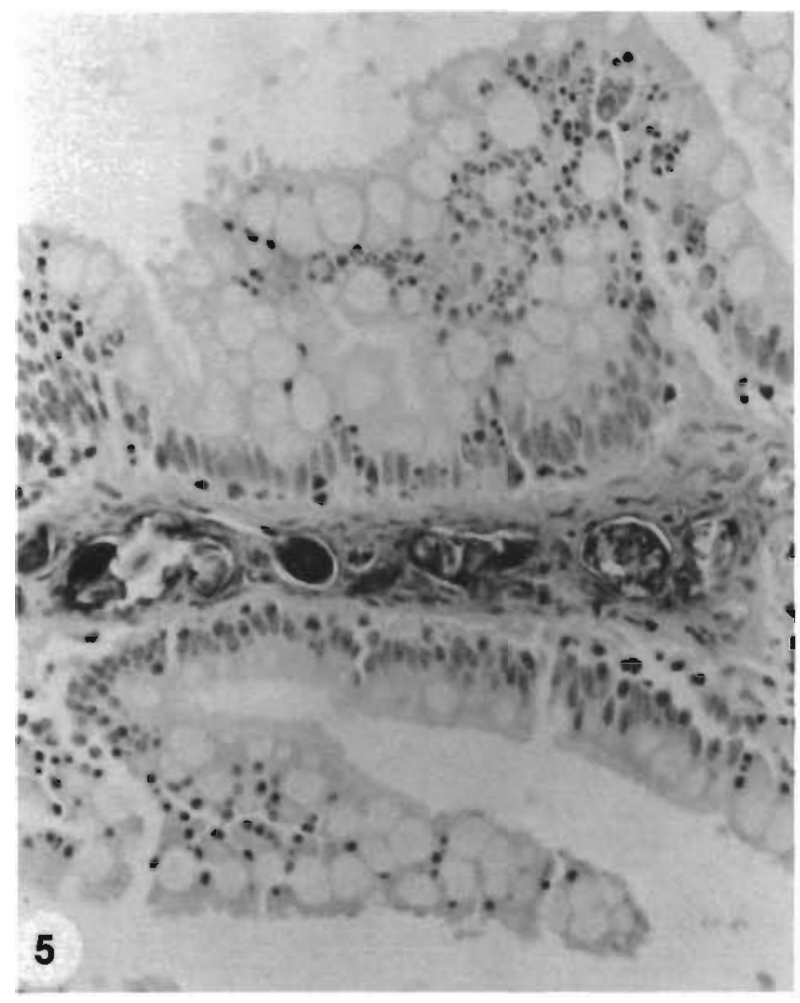

Figs. 1 to 5. Salmo salar. Stored tissue specimens collected during the first known outbreak of CV in 1977. All specimens counterstained with haematoxylin. Fig. 1. Heart. Positive focal reaction extracellularly between the compact and the spongeous part of the myocardium (arrows). Single bacteria could not be identified. $\times 100$. Fig. 2. Liver. Positive reaction of hepatocyte vesicular membranes (arrows). The vesicles are probably fat vacuoles. $\times 400$. Fig. 3. Spleen. Positive reaction intra- and extracellularly in the white pulp (arrows). $\times 250$. Fig. 4 . Kidney. Intracellular positive reaction of intertubular cells (possibly macrophages) (arrows). Melanomacrophages are also evident $\left({ }^{\circ}\right)$ but no reaction was observed in these cells. There is marked intercellular edema. $\times 400$. Fig. 5. Fore-gut. An intense reaction is present intra- and perivascularly in fore-gut lamina propria. No reaction is observed in the epithelium. $\times 250$

$8{ }^{\circ} \mathrm{C}$. Salinity was 29 to $30 \%$. V. salmonicida $(88 / 09 /$ 173 of National Veterinary Institute Culture Collection) was grown on blood-agar plates (containing $2 \% \mathrm{NaCl}$ ) for $4 \mathrm{~d}$ at $15^{\circ} \mathrm{C}$, harvested, and suspended in sterile $0.1 \mathrm{M}$ phosphate-buffered saline (PBS). Each fish was injected intraperitoneally with $10^{6}$ bacteria $(0.1 \mathrm{ml} \mathrm{PBS}$ suspension per fish). Fish were killed on Days 5, 4, 7, and 11 after injection. Organ samples were collected from heart, liver, spleen, kidney, fore-gut, and musculature. The samples were fixed immediately in $10 \%$ phosphate-buffered formalin, and processed routinely. Negative controls (from seawater) were collected from the same lot of fish as that used in the experiment, but prior to the experiment. Negative controls were also collected from parr (ca $30 \mathrm{~g}$ ) held in fresh water.
Stored tissue. Tissue samples were collected from heart, liver, spleen, kidney, fore-gut, and musculature. Samples from moribund and dead fish involved in the first outbreak of the disease were fixed in $10 \%$ phosphate-buffered formalin and stored in paraffin. For immunohistochemical studies, samples were cut at 5 to $6 \mu \mathrm{m}$, and placed on gelatin-coated slides.

Monoclonal antibodies. MAbs, $2 \mathrm{~B} 5$ and $7 F 3$, produced as previously described (Espelid et al. 1988), were used for immunohistochemistry. Both MAbs were of the IgGl, kappa isotype. Hybridoma ascites was produced by injecting $10^{5}$ to $10^{6}$ Vibrio salmonicida cells intraperitoneally into mice. Ascitic fluid was collected 7 to $21 \mathrm{~d}$ later (Espelid et al. 1988). The MAbs used in this study showed a specificity for VS-P1, or more precisely, the lipopolysaccaride (LPS) moiety of the VS-P1 complex (Bogwald et al. 1990).

Heterologous MAbs of the same isotype were used as a negative control.

Bacteriological examination. Bacteriological examination was carried out on kidney samples from all of the control fish included in the experiment. Cultivation was performed on blood-agar plates with $2 \% \mathrm{NaCl}$ at $15^{\circ} \mathrm{C}$ for at least $6 \mathrm{~d}$. Vibrio salmonicida was identified by an ELISA technique performed as previously described (Espelid et al. 1988).

Immunohistochemistry. The immunohistochemical procedure was performed according to the avidinbiotin complex (ABC) method (Hsu et al. 1981). The sections were deparaffinized at 58 to $59^{\circ} \mathrm{C}$ for $30 \mathrm{~min}$, washed in 2 xylene baths, and rehydrated through a series of ethanols $(100,96$, and $70 \%)$. Endogenous peroxidase activity was blocked by incubating for 20 min with methanol $(100 \%)$ containing $3 \% \mathrm{H}_{2} \mathrm{O}_{2}$. Sections were then washed in PBS for $10 \mathrm{~min}$. Following this, the sections were incubated with $25 \%$ bovine serum albumin (BSA) in PBS for 20 min. They were then blotted dry and reacted with primary antibody (2B5 and $7 \mathrm{~F} 3$ diluted 1/5000) in PBS containing $12.5 \%$ BSA as diluent. After 10 min washing in PBS, the secondary antibody [antimouse immunoglobulins (Dako) conjugated to biotin] was applied to the specimens at a dilution of 1/300, and incubated for 30 min. After 10 min washing in PBS, the avidin-biotinperoxidase complex (diluted 1/300) was applied and incubated for ca 30 to $60 \mathrm{~min}$. The sections were then washed in PBS for $10 \mathrm{~min}$, and incubated for 10 min with $0.03 \% \mathrm{H}_{2} \mathrm{O}_{2}$ and $0.06 \%$ 3,3'-diaminobenzidine tetrahydrochloride (Sigma) in $0.05 \mathrm{M}$ imidazole buffer, $\mathrm{pH}=7.4$. After ca 1 min washing in tap water, the section were counterstained with Harris haematoxylin $(\mathrm{H})$ for $2 \mathrm{~min}$, washed in tap water, and dehydrated through an ethanol series $(70,96$, and $100 \%)$, and 2 xylene baths. Coverslips were mounted with Eukitt. 


\section{RESULTS}

Vibrio salmonicida in the positive controls was identified by bacteriological examination and an ELISAtechnique. It was also identified in situ in tissue samples collected from the infection experiment in 1989, using clone $2 \mathrm{~B} 5$ and $7 \mathrm{~F} 3$. $V$. salmonicida, or its products, were also identified in stored paraffin-embedded tissue specimens from 1977. The results obtained for tissues from the 2 different sources were comparable.

In heart tissue a positive reaction was visualized as a brown colour, mostly extracellularly, between the compact and the spongeous part of the myocardium (Fig. 1). The reaction occurred in both a diffuse and a focal form. It was not possible to identify single bacteria. In the livel, distinct coioration of the hepatocyte intracellular vesicle membranes was observed (Fig. 2). A positive reaction was present within phagocytic cells of the splenic white pulp and the intertubular cells of the kidney. In addition, positive extracellular reactions were present in both of these organs (Figs. $3 \& 4$ ). The positively coloured cells in both organs, were judged to be phagocytic cells (macrophages).

A focal to diffuse positive reaction was present within and around vessels of the foregut lamina propria, as well as in the lamina propria per se. (Fig. 5).

No reaction was observed in tissue specimens from negative control fish held in sea or fresh water. A heterologous MAb of the same isotype was also applied on positive and negative control tissues and on stored tissue specimens from the 1977 outbreak. All gave negative results.

\section{DISCUSSION}

This study showed that Vibrio salmonicida, or its products, could be identified by immunohistochemistry in formalin-fixed, paraffin-embedded tissue specimens from Atlantic salmon suffering from experimentally induced cold-water vibriosis, and also in stored tissue specimens collected during the first outbreak of the disease in Norway in 1977. These findings are consistent with other reports concerning the aetiology of the 1977 outbreak of the disease.

The nutritional aspects of 'Hitra disease' or CV have been thoroughly discussed by various authors (Fjølstad \& Heyeraas 1985, Poppe et al. 1986), deficiencies in dietary vitamin $E$ and selenium being hypothesized as the cause of the disease. This possibility had been suggested because of the similarity between the lesions seen in mammals with such deficiencies (Hulland 1985) and those appearing in Atlantic salmon with 'Hitra disease (Poppe et al. 1986). Vibrio salmonicida recovered from diseased fish was considered as a sec- ondary invader (Poppe et al. 1986). However, a study of plasmid profiles of Vibrio-like isolates from Atlantic salmon suffering from 'Hitra disease' has shown that these bacteria exhibit an extensive homology in their content of cryptic plasmids (Sørum et al. 1988). These findings do not support the hypothesis that $V$. salmonicida is an occasional secondary invader. Furthermore, the disease can be reproduced under experimental conditions (Bruno et al. 1985), and vaccination against $V$ salmonicida provides a very high level of protection against the disease (Holm et al. 1987, Lillehaug 1989). There thus seems to be good evidence that $V$. salmonicida is the causative agent of cold-water vibriosis.

Over the last 2 decades, immunohistochemistry utilizing enzymes to produce coloured reactants has supplied important investigative and diagnostic histological tools (Rickert \& Maliniak 1989). The tools permit the in situ identification of tissue constituents by means of antigen-antibody reactions, and there seems to be no limit to the range of substance that may be detected in this way (Noorden 1986). In this study, it was not possible to identify single bacteria in the tissue specimens, and the specific coloration in heart specimens was focal or diffuse, and was located extracellularly between the compact and the spongeous tissues. Similar diffuse extracellular staining was seen in organ specimens from the spleen and kidney. Vibrio salmonicida produces an LPS-containing surface layer complex, VS-P1 (Bøgwald et al. 1990), and VS-P1 is released into the surroundings during growth in the host (Espelid et al. 1988). Furthermore, VS-P1 can be detected in high concentrations in sera from Atlantic salmon suffering from cold-water vibriosis (Hjelmeland et al. 1988). The diffuse staining pattern demonstrated in specimens from the heart, spleen, and kidney seems to reflect the above mentioned observations.

Negative controls including fish held in either sea water or in fresh water gave no reactions. Similar negative reactions were obtained when a heterologous $\mathrm{MAb}$ was applied. The tissue reactions were easy to read and no interpretative difficulties were experienced. The specific identification of the VS-P1 antigen in the tissues by clone $2 \mathrm{~B} 5$ and $7 \mathrm{~F} 3$ provides strong additional evidence that Vibrio salmonicida was the causative agent of the first outbreak of the disease. Furthermore, based on this investigation one might state that immunohistochemical techniques can be used by anyone on stored, fixed material who wants to study the history of a pathogen in a particular location. The only requirement is that specific polyclonal or monoclonal antibodies are available.

In conclusion, the present study showed that antigens specific for Vibrio salmonicida could be identified in formalin-fixed, paraffin-embedded tissue specimens 
from Atlantic salmon suffering from cold-water vibriosis, and also in tissue specimens collected during the first outbreak of the disease in 1977. The findings offer additional evidence for the bacterium as the causative agent of 'Hitra disease'.

Acknowledgements. The skilful technical assistance of Ms Randi Terland, and the valuable discussions with Dr $\varnothing$. $\varnothing$ degaard are gratefully appreciated. This investigation was supported by Grant 102698 from the Norwegian Agricultural Research Council.

\section{LITERATURE CITED}

Bruno, D. W., Hastings, T. S., Ellis, A. E., Wootten, R. (1985). Outbreak of a cold-water vibriosis in Atlantic salmon in Scotland. Bull. Eur. Ass. Fish. Pathol. 5: 62-63

Bøgwald, J., Stensvåg, K., Hoffman, J., Espelid, S., Holm, K. O., Jørgensen, T. (1990). Electrophoretic and immunochemical analysis of surface antigens of the fish pathogens Vibrio salmonicida and Vibrio anquillarum. J. Fish Dis. 13: 293-301

Egidius, E., Andersen, K., Clausen, E., Raa, J. (1981). Coldwater vibriosis or 'Hitra disease' in Norwegian salmonid farming. J. Fish Dis. 4: 353-354

Egidius, E., Solheim, Ø., Andersen, K. (1984). Further observations on cold-water vibriosis or Hitra disease. Bull. Eur. Ass. Fish Pathol. 4: 50-51

Espelid, S., Holm, K. O., Hjelmeland, K., Jørgensen, T. (1988). Monoclonal antibodies against Vibrio salmonicida: the causative agent of cold-water vibriosis ('Hitra disease') in Atlantic salmon, Salmo salar L. J. Fish Dis. 11: 207-214

Fjølstad, M., Heyeraas, A. L. (1985). Muscular and myocardial degeneration in cultured Atlantic salmon, Salmo salar L., suffering from 'Hitra disease'. J. Fish Dis. 8: 367-372

Hjelmeland, K., Stensvåg, K., Jørgensen, T., Espelid, S. (1988). Isolation and characterization of a surface layer antigen from Vibrio salmonicida. J. Fish Dis. 11: 197-205

Responsible Subject Editor: T. Evelyn, Nanaimo, B.C., Canada
Holm, K. O. (1985). Isolering og karakterisering av Vibriobakterier fra laks (Salmo salar L.) med Hitrasyke. [Isolation and characterization of Vibrio-bacteria from salmon (Salmo salar L.) suffering from 'Hitra disease']. Thesis, Univ. of Tromsø

Holm, K. O., Strøm, E., Stensvåg, K., Raa, J., Jørgensen, T. (1985). Characteristics of a Vibrio sp. associated with the 'Hitra disease' of Atlantic salmon in Norwegian fish farms. Fish Pathol. 20: 125-129

Holm, K. O., Jørgensen, T (1987). A successful vaccination of Atlantic salmon, Salmo salar L., against 'Hitra disease' or cold-water vibriosis. J. Fish Dis. 10: 85-90

Hsu, S., Raine, L., Fanger, H. (1981). Use of avidin-biotinperoxidase complex $(\mathrm{ABC})$ in immunoperoxidase techniques: a comparison between $\mathrm{ABC}$ and unlabeled antibody (PAP) procedures. J. Histochem. Cytochem. 29: $577-580$

Hulland, T. J. (1985). Nutritional myopathy. In: Jubb, K. V. F., Kennedy, P. C., Palmer, N. (eds.) Pathology of domestic animals. Academic Press, London, p. 168-174

Lillehaug, A. (1990). A field trial of vaccination against coldwater vibriosis in Atlantic salmon (Salmo salar L.). Aquaculture 84: 1-12

Noorden, S. van (1986). Tissue preparation and immunostaining techniques for light microscopy. In: Noorden, S. van, Ritter, M. A. (eds.) Immunohistochemistry in diagnostic pathology. Academic Press, London, p. 26-53

Poppe, T. T., Frøslie, A., Koppang, N., Håstein, T. (1985). Muskeldegenerasjon med eksudativ hemorrhagisk diatese hos oppdrettslaks - 'Hitrasjuke'. (Muscular dystrophy with exudative haemorthagic diathesis in farmed Atlantic salmon - 'Hitra disease'). Nor. Vet. Tidssk. 97: 159-165

Poppe, t. T., Håstein, T., Frøslie, A., Koppang, N., Norheim, G. (1986). Nutritional aspects of haemorrhagic syndrome ('Hitra disease') in farmed Atlantic salmon Salmo salar. Dis, aquat. Org. 1: 155-162

Rickert, R. R., Maliniak, R. M. (1989). Intralaboratory quality assurance of immunohistochemical procedures. Arch. Pathol. Lab. Med. 113: 673-679

Sørum, H., Poppe, T. T., Olsvik, $\varnothing .(1988)$. Plasmids in Vibrio salmonicida isolated from Salmonids with Hemorrhagic Syndrome (Hitra disease). J. clin. Microbiol. 26: 1679-1683

Manuscript first received: December 12, 1989

Revised version accepted: March 21, 1991 